\title{
COVID-19: Impact in endothelial function and therapy with Mesenchymal Stromal Cells
}

\author{
La COVID-19: Impacto en la función endotelial y terapia con \\ célullas estromales mesenquimales
}

\author{
Carla Longo Freitas (iD Priscilla Yuri Okochi Alves da silva (iD) Maria do Carmo Pinho Franco (iD Danilo Candido de Almeida*
}

Open Access

*Correspondence:

gudaalmeida@gmail.com

Department of Medicine. Nephrology

division. Federal University of São

Paulo, Brazil

First draft submitted: 15-05-2021

Accepted for publication:

23-07-2021

Published online: 09-09-2021

Key words:

COVID-19 pathophysiology;

endothelial disfunction;

immune cells;

mesenchymal stromal cells;

pathogenesis.

Palabras clave:

Células estromales

mesenquimales;

células inmunes;

disfunción endotelial

fisiopatología de la COVID-19;

patogénesis

Citation:

Longo de Freitas C, Okochi Alves da silva PY, Pinho Franco M do C de Almeida DC. COVID-19: Impact in endothelial function and therapy with Mesenchymal Stromal Cells. Magna Scientia UCEVA 2021;1: 6-10. https://doi.org/10.54502/msuceva. v1n1a2.

\section{Abstract}

The new pandemic of SARS-CoV-2 Betacoronavirus, has spread worldwide, and infected millions of individuals causing the disease denominated of COVID-19. Further on flu symptoms, due to the high tropism of virus, has most been observed in the COVID-19 pathophysiology: acute heart failure, thromboembolism events, acute renal failure, neurological and liver damage, and multiple organ failure, with special attention to endothelial disfunction. Hence, elucidate whether virus target the endothelium is a crucial step to understand COVID-19 pathogenesis. However, the permissiveness of blood vessels during SARS-CoV-2 infection remains unclear, but regardless endothelial infection, the vascular disfunction may occurred in response to molecular inflammatory signaling triggered by immune cells that attempt to limit infection. Thus, alternative therapies using mesenchymal stromal cells (MSCs) can change this scenario and help critically ill patients. In this reflection, we attempt to discuss COVID-19 pathophysiology with impact in endothelial function and explore the applicability of MSC-based therapies as alternative treatment.

\section{Resumen}

La nueva pandemia de Betacoronavirus SARS-CoV-2, se ha extendido por todo el mundo y ha infectado a millones de personas, causando la enfermedad denominada COVID-19. Además de los síntomas de gripe, debido al alto tropismo del virus, se han observado principalmente en la fisiopatología de la COVID-19: insuficiencia cardíaca aguda, eventos de tromboembolismo, insuficiencia renal aguda, daño neurológico y hepático y falla multiorgánica, con especial atención a la disfunción endotelial. Por lo tanto, dilucidar si el virus se dirige al endotelio es un paso crucial para comprender la patogénesis de COVID-19. Sin embargo, la permisividad de los vasos sanguíneos durante la infección por SARS-CoV-2 sigue sin estar clara, pero independientemente de la infección endotelial, la disfunción vascular puede ocurrir en respuesta a la señalización inflamatoria molecular desencadenada por células inmunes que intentan limitar la infección. Por lo tanto, las terapias alternativas que utilizan células estromales mesenquimales (MSC) pueden cambiar este escenario y ayudar a los pacientes críticamente enfermos. En esta reflexión, intentamos discutir la fisiopatología de COVID-19 con impacto en la función endotelial y explorar la aplicabilidad de terapias basadas en MSC como tratamiento alternativo. 


\section{COVID-19 and Sars-Cov-2 pathophysiology}

Currently, the world is facing the new pandemic of SARSCoV-2 coronavirus, responsible for the COVID-19 disease. SARS-CoV-2 is a positive single-stranded RNA-virus belonging to subgroup of Betacoronavirus of the Coronaviridae family [1]. The disease is similar to the severe acute respiratory syndrome (SARS), which was the first coronavirus (SARS-CoV-1) epidemic in the world registered in southeastern China [2-4]. To date (September 2021) around 218.946 .836 people, have been diagnosed worldwide with SARS-CoV-2 infection, with 4.539.723 deaths and 5.289.724.918 vaccine doses distributed. Specifically, in the American continent, was confirmed 84.498.889 cases, with 2.043.623 deaths, according to data from the World Health Organization (WHO) [5].

The most common symptoms in mild to moderate cases of the disease are fever, dry cough, throat irritation, breathing difficulty, myalgia, nausea and/or vomiting, diarrhea, headache [6,7]; and more specifically, asnomy or augesia [8]. Additionally, critically ill patients also present profound lymphopenia, caused by SARS-CoV-2 infection [9-11].

Due to the high tropism of virus at tissues as heart, kidney and blood vessels has been observed in the pathophysiology of COVID-19: acute heart failure, dysrhythmia, myocarditis, thromboembolism events (arterial and venal) [7]; acute renal failure [12,13]; neurological damage such as impaired consciousness, stroke; liver dysfunction; blood dysfunction (i.e. metabolic acidosis) [6]; thrombosis [14]; septic shock and multiple organ failure $[15,16]$.

In this context, to enter in host cell, the SARS-CoV-2 virus bind its surface protein (Spike $S$ ) with the angiotensin II converting enzyme (receptor ACE2), turning some subunits of its protein $\mathrm{S}$ editable by proteolytic enzyme as TMPRSS2, which cleaves protein S into S1, S2 and S2' counterparts promoting cellular infection $[17,18]$. Both ACE2 and TMPRSS2 receptors are widely distributed in alveolar cells, kidney, and also in many other organs, especially in the capillary endothelium [1].
The endothelium consists in a semi-permeable barrier between body fluids and tissues, comprising an extensive network for micro and macromolecules transportation including cells. Thus, elucidate whether virus target the endothelium in a direct way or as bystanders, is a crucial step to understand COVID-19 pathogenesis. The permissiveness of endothelial cells during SARS-CoV-2 infection is controversial and remains unclear. Fosse et al. [19], demonstrated that only human coronary artery endothelial cells (HCAECs) were infected by SARS-CoV-2 virus when compared to five other different endothelial cell lineages, however, did not promote virus replication. Conversely, Liu et al. [20], identified in lungs of both nonhuman primates and autopsied COVID-19 patients that SARS-CoV-2 directly infects mature vascular endothelial cells [20]. However, regardless endothelial infection, the vascular disfunction in COVID-19 patients may occurred as a result of molecular inflammatory signaling from infected cells or collateral tissue damage when immune cells attempt to limit infection.

This step initiates in the early stages of SARS-CoV-2 infection mainly at nasal epithelial cells, bronchial cells, and pneumocytes. When the virus reaches the alveolar lumen, it triggers an inflammatory response that promote the recruitment of immune cells such as neutrophils, monocytes, and $\mathrm{T}$ cells, which become infected $[21,22]$. In sequence, the virus overactive an inflammatory cascade in these immune cells accompanied by extensive release of molecules (i.e., IL-2, IL-6, IL-7, GSCF, IP-10, MCP1, MIP1A and TNF- $\alpha$ ), which was widely known as "cytokine storm", that attack principally surround tissues as lung and endothelium [10]. Hence, this immunological disorder, in severe cases, affects the tissue homeostasis leading to even more serious secondary complications such as multiorgan failure.

\section{MSC homing and immunomodulation}

Over the last decade, mesenchymal stromal cells (MSCs) have been the focus of many cell-based therapies to treat various type of disorders, including metabolic, degenerative, and inflammatory diseases, with focus in supporting tissue repair and regeneration of damaged tissues (see figure 1). MSCs have the ability to influence the tissue behavior (i.e., endothelial tissue), and vice- 
versa. This crosstalk involves the selective migration ability of MSCs toward sites of injury, a phenomenon called "homing". This homing process is promoted by specific chemokines and cytokines secreted by damage cells (EGF, IGF, PDGF, VEGF, SDF-1, TNF- $\alpha$, IL-1, IL6, IL-8, VCAM-1, MCP-1, MCP-3, and G-CSF), which are chemo-attractive and trigger MSCs mobilization (figure 1).

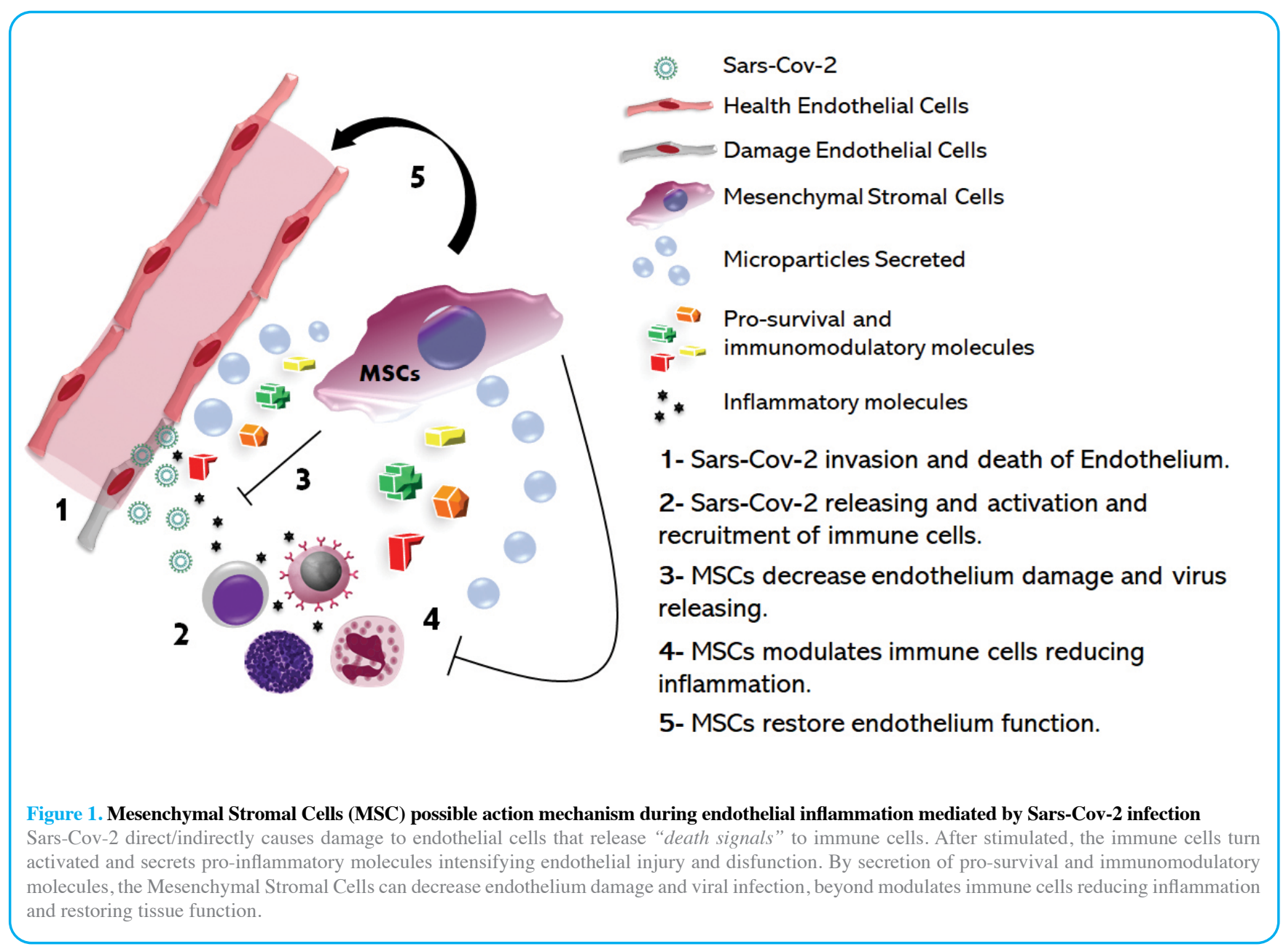

At injury site, ligand-receptor interactions with adhesion molecules (selectins and integrins) are necessary for MSCs adhesion and rolling into injured tissues [23].After tissue internalization, the MSCs alter the microenvironment through secretion of paracrine regulatory factors such as cytokines, chemokines and growth factors (IDO-1, PGE-2, iNOS, IL-6, TGF- $\beta$, HGF, and HLA-G5), that not only modulates cells but present angiogenic, anti-inflammatory, anti-fibrotic and immunosuppressive properties, modulating the function of immune cell (i.e., B and T lymphocytes, dendritic cells, natural killer cells, monocytes, neutrophils, and macrophages), and promoting tissue repair [24]. Taken together, these properties have led to the use of MSCs as an attractive and promising cell therapy in the context of acute respiratory distress syndrome (ARDS) seen in severe COVID-19 patients (figure 1).

\section{MSC and COVID-19: perspectives and new insights}

Clinical applications of MSCs have been registered at the National Institute of Health Clinical Trials [25] about COVID-19. In fact, there are 39 recruiting and ongoing 
interventional trials studying MSCs to the treatment of ARDS, pneumonia, cytokine storm, pulmonary infection, SARS-Cov-2 induced pulmonary fibrosis and acute kidney injury, in the context of COVID-19 complications (September, 2021). These clinical trials involve MSCs derived from Wharton Jelly, adipose tissue, umbilical cord, placenta and human dental pulp and bone marrow as source of treatment or combined with other drugs such as oseltamivir, hormones, azithromycin, antibiotics, or hydroxychloroquine. Although, cell source, dosage and timing has not been stablished yet, these clinical studies are critical and can bring encouraging results, considering that phase I and II trials, have already demonstrated a partial effectiveness of MSCs treatment, where a reduction in inflammatory serologic markers and shorter-time period of hospitalization were observed [26].

In summary, MSC-based therapies can provide valuable information in the course of new treatment and new strategies to modulate endothelial function, and other tissues, specifically in the context of COVID-19.

\section{Consent for publication}

Authors read and approved the final manuscript.

\section{Competing interests}

Authors declares have no competing interests. This document only reflects the points of view of the authors and not those of their institutions.

\section{Author details}

\section{Carla Longo Freitas}

Received his $\mathrm{PhD}$ degree in Immunology from Federal University of São Paulo, São Paulo, Brazil. Currently, she is pursuing a postdoctoral stay in the Department of Medicine, Discipline of Nephrology, Federal University of São Paulo-Escola Paulista de Medicina (UNIFESP/EPM). She aims to investigate the impact of COVID-19 on the kidneys and endothelium, studying the in vitro infection by SARS-CoV-2 in renal and endothelial cells; and the therapeutic potential of mesenchymal stem cells.
Priscilla Yuri Okochi Alves da Silva

She is a doctoral student in the Department of Immunology, Institute of Biomedical Sciences, University of São Paulo, Brazil (UNIFESP/ Brazil). Her research line is defined as "use of organ-on-chip to study the endothelium-kidney axis in SARS-CoV-2 infection; and therapeutic strategies with Mesenchymal Stem Cells.”, graduated in Biomedicine at the University Center of Faculdades Metropolitanas Unidas (FMU/Brazil), completed in 2013. Areas of expertise: medicine, biological sciences, immunology and microbiology.

\section{Maria do Carmo Pinho Franco}

Studied Biomedicine and she started his research career at the department of pharmacology at the University of São Paulo where she also accomplished his doctoral thesis. In the following years she worked in the field of vascular biology with the focus on fetal programming. The main topics of her research group are fetal programming of cardiovascular diseases and exploration of novel targets

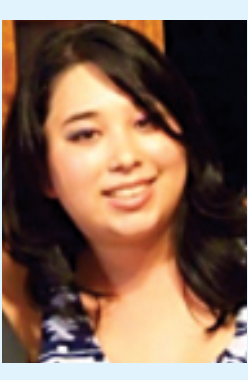
involved in the development of cardiometabolic disease focusing on endothelial function as well as biomarker research.

\section{Danilo Candido de Almeida}

Is Doctor in Biomedical Sciences (MedicineNephrology) from the Federal University of São Paulo - UNIFESP with Post-doctorate at the Federal University of São Paulo (Nephrology), University of São Paulo (Immunology) and at the Helmholtz-Institute for Biomedical Engineering - RWTH Aachen University (Aachen, Germany). $\mathrm{He}$ is currently an Associate Professor and Advisor

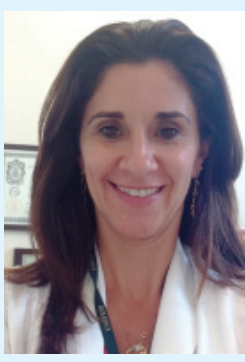
at the Department of Medicine, Discipline of Nephrology at the Federal University of São Paulo. Dr Almeida has experience in Cell Biology, Molecular Biology and Genetics, with an emphasis on the function of micromolecules. Main topics are as follows: mesenchymal stem cell, cell therapy, large-scale data analysis and experimental model of inflammatory and renal lesions.

\section{References}

[1] Zhou P, Yang X-L, Wang X-G, Hu B, Zhang L, Zhang W, et al. A pneumonia outbreak associated with a new coronavirus of probable bat origin. Nature 2020;579. https://doi.org/10.1038/ s41586-020-2012-7.

[2] Tsang KW, Ho PL, Ooi GC, Yee WK, Wang T, Chan-Yeung $\mathrm{M}$, et al. A Cluster of Cases of Severe Acute Respiratory Syndrome in Hong Kong. New England Journal of Medicine 2003;348. https://doi.org/10.1056/NEJMoa030666.

[3] Lee N, Hui D, Wu A, Chan P, Cameron P, Joynt GM, et al. A Major Outbreak of Severe Acute Respiratory Syndrome in Hong Kong. New England Journal of Medicine 2003;348. https://doi. org/10.1056/NEJMoa030685. 
[4] Cheng VCC, Lau SKP, Woo PCY, Yuen KY. Severe Acute Respiratory Syndrome Coronavirus as an Agent of Emerging and Reemerging Infection. Clinical Microbiology Reviews 2007;20. https://doi.org/10.1128/CMR.00023-07.

[5] World Health Organization (WHO). WHO Coronavirus (COVID-19) Dashboard. WHO Covid-19 Homepage 2021. https://covid19.who.int/.

[6] Mao R, Qiu Y, He J-S, Tan J-Y, Li X-H, Liang J, et al. Manifestations and prognosis of gastrointestinal and liver involvement in patients with COVID-19: a systematic review and meta-analysis. The Lancet Gastroenterology \& Hepatology 2020;5. https://doi.org/10.1016/S2468-1253(20)30126-6.

[7] Levi M, Thachil J, Iba T, Levy JH. Coagulation abnormalities and thrombosis in patients with COVID-19. The Lancet Haematology 2020;7. https://doi.org/10.1016/S2352-3026(20)30145-9.

[8] Spinato G, Fabbris C, Polesel J, Cazzador D, Borsetto D, Hopkins C, et al. Alterations in Smell or Taste in Mildly Symptomatic Outpatients With SARS-CoV-2 Infection. JAMA 2020;323. https://doi.org/10.1001/jama.2020.6771.

[9] Wu C, Chen X, Cai Y, Xia J, Zhou X, Xu S, et al. Risk Factors Associated with Acute Respiratory Distress Syndrome and Death in Patients with Coronavirus Disease 2019 Pneumonia in Wuhan, China. JAMA Internal Medicine 2020;180. https:// doi.org/10.1001/jamainternmed.2020.0994.

[10] Huang C, Wang Y, Li X, Ren L, Zhao J, Hu Y, et al. Clinical features of patients infected with 2019 novel coronavirus in Wuhan, China. The Lancet 2020;395. https://doi.org/10.1016/ S0140-6736(20)30183-5.

[11] Guan W, Ni Z, Hu Y, Liang W, Ou C, He J, et al. Clinical Characteristics of Coronavirus Disease 2019 in China. New England Journal of Medicine 2020;382. https://doi. org/10.1056/NEJMoa2002032.

[12] Chen Y-T, Shao S-C, Hsu C-K, Wu I-W, Hung M-J, Chen Y-C. Incidence of acute kidney injury in COVID-19 infection: a systematic review and meta-analysis. Critical Care 2020;24. https://doi.org/10.1186/s13054-020-03009-y.

[13] de Almeida DC, Franco M do CP, dos Santos DRP, Santos MC, Maltoni IS, Mascotte F, et al. Acute kidney injury: Incidence, risk factors, and outcomes in severe COVID-19 patients. PLOS ONE 2021;16. https://doi.org/10.1371/journal.pone.0251048.

[14] Yang X, Yu Y, Xu J, Shu H, Xia J, Liu H, et al. Clinical course and outcomes of critically ill patients with SARS-CoV-2 pneumonia in Wuhan, China: a single-centered, retrospective, observational study. The Lancet Respiratory Medicine 2020;8. https://doi.org/10.1016/S2213-2600(20)30079-5.

[15] Grasselli G, Zangrillo A, Zanella A, Antonelli M, Cabrini L, Castelli A, et al. Baseline Characteristics and Outcomes of
1591 Patients Infected With SARS-CoV-2 Admitted to ICUs of the Lombardy Region, Italy. JAMA 2020;323. https://doi. org/10.1001/jama.2020.5394.

[16] Lam TT-Y, Jia N, Zhang Y-W, Shum MH-H, Jiang J-F, Zhu $\mathrm{H}-\mathrm{C}$, et al. Identifying SARS-CoV-2-related coronaviruses in Malayan pangolins. Nature 2020;583. https://doi.org/10.1038/ s41586-020-2169-0.

[17] Glowacka I, Bertram S, Muller MA, Allen P, Soilleux E, Pfefferle S, et al. Evidence that TMPRSS2 Activates the Severe Acute Respiratory Syndrome Coronavirus Spike Protein for Membrane Fusion and Reduces Viral Control by the Humoral Immune Response. Journal of Virology 2011;85. https://doi.org/10.1128/JVI.02232-10.

[18] Hoffmann M, Kleine-Weber H, Schroeder S, KrŸ ger N, Herrler T, Erichsen S, et al. SARS-CoV-2 Cell Entry Depends on ACE2 and TMPRSS2 and Is Blocked by a Clinically Proven Protease Inhibitor. Cell 2020;181.https://doi.org/10.1016/j.cell.2020.02.052.

[19] Fosse JH, Haraldsen G, Falk K, Edelmann R. Endothelial Cells in Emerging Viral Infections. Frontiers in Cardiovascular Medicine 2021;8. https://doi.org/10.3389/fcvm.2021.619690.

[20] Liu F, Han K, Blair R, Kenst K, Qin Z, Upcin B, et al. SARSCoV-2 Infects Endothelial Cells In Vivo and In Vitro. Frontiers in Cellular and Infection Microbiology 2021;11. https://doi. org/10.3389/fcimb.2021.701278.

[21] Mancia G, Rea F, Ludergnani M, Apolone G, Corrao G. Renin-Angiotensin-Aldosterone System Blockers and the Risk of Covid-19. New England Journal of Medicine 2020;382. https://doi.org/10.1056/NEJMoa2006923.

[22] Fosb, 1 EL, Butt JH, `stergaard L, Andersson C, Selmer C, Kragholm K, et al. Association of Angiotensin-Converting Enzyme Inhibitor or Angiotensin Receptor Blocker Use With COVID-19 Diagnosis and Mortality. JAMA 2020;324. https:// doi.org/10.1001/jama.2020.11301.

[23] NassiriSM, RahbarghaziR. Interactions of Mesenchymal Stem Cells with Endothelial Cells. Stem Cells and Development 2014;23. https://doi.org/10.1089/scd.2013.0419.

[24] Saeedi P, Halabian R, Imani Fooladi AA. A revealing review of mesenchymal stem cells therapy, clinical perspectives and modification strategies. Stem Cell Investigation 2019;6:1-8. https://doi.org/10.21037/sci.2019.08.11

[25] Clinical Trials.gov. Federally-funded clinical studies related to COVID-19. NIH US National Library of Medicine 2021. https://clinicaltrials.gov/.

[26] Durand N, Mallea J, Zubair AC. Insights into the use of mesenchymal stem cells in COVID-19 mediated acute respiratory failure. Npj Regenerative Medicine 2020;5. https://doi.org/10.1038/s41536-020-00105-z. 